\title{
Commentary: Something made from nothing_impressive, but will it last?
}

\author{
Ronald K. Woods, MD, PhD
}

From the Division of Pediatric Cardiothoracic Surgery, Department of Surgery, Medical College of Wisconsin, and Herma Heart Institute, Children's Hospital of Wisconsin, Milwaukee, Wis.

Disclosures: Dr Woods is co-founder of OperVu, Inc, which has no relationship to the content of this work.

Received for publication Sept 17, 2019; revisions received Sept 17, 2019; accepted for publication Sept 18, 2019; available ahead of print Oct 23, 2019

Address for reprints: Ronald K. Woods, MD, PhD, Department of Surgery Medical College of Wisconsin, Division of Pediatric Cardiothoracic Surgery, Children's Hospital of Wisconsin, 9000 W Wisconsin Ave, MS B 730, Milwaukee, WI 53226 (E-mail: rwoods@chw.org).

J Thorac Cardiovasc Surg 2020;159:1982-3

$0022-5223 / \$ 36.00$

Copyright (c) 2019 by The American Association for Thoracic Surgery

https://doi.org/10.1016/j.jtcvs.2019.09.099

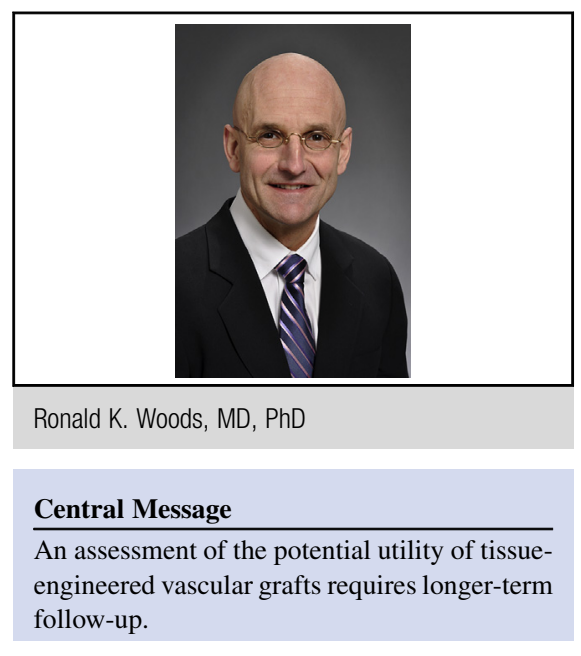

See Article page 1971.
I congratulate Yeung and colleagues ${ }^{1}$ for their development of an elegant, sophisticated, and innovative technology and also commend their collaboration across multiple disciplines and institutions. The basic concept they promote is intuitively very appealing - use patient-specific anatomy, guided by computational fluid dynamics, to develop 3-dimensional (3D) vascular grafts tailored to a given patient's specific needs-in this particular case, the creation of bifurcated pulmonary artery grafts. The reader should look beyond the fact that both animals originally had normal anatomy, as I presume the computer-aided design phase would permit creation of any desired anatomy (for missing parts), which could then be modified to fit the patient's true anatomy. Computational fluid dynamics would then refine the model for function and subsequent 3D printing, mandrel formation, and electrospinning to create the graft.

The combination of 3D printing and electrospinning represents a newer generation of decades of effort in the field of tissue engineering and has incredible implications for replacing diseased or missing parts of anatomy. However, an enormity of variables complicate engineering blood vessels. $^{2}$ Of the few reports in humans using tissue-engineered grafts predominantly for the Fontan procedure, Sugiura and others $^{3-5}$ have reported the longest-term follow-up. At 11 years, $28 \%$ of patients had undergone angioplasty for graft stenosis. ${ }^{3}$ The only other in-human application has been for arteriovenous fistulae for dialysis access with 1year primary patency rates of approximately $30 \%{ }^{6}$ A recent study in immunodeficient mice offers some sobering, instructive insight. ${ }^{7}$ The authors compared 3-mm length grafts placed in the intra-abdominal aorta and inferior vena cava and examined them throughout the period required for resorption of the polymer. Grafts in the inferior vena cava performed very well, whereas all grafts in the intra-abdominal aorta failed due to aneurysm formation and rupture. In their review of the literature, the authors comment that there has yet to be a report of an electrospun graft fully degrading and remodeling into a functional neovessel in vivo.

With regard to the present report and an anticipated resorption period of 6 months for the polymer, 2 animals and 1 month of follow-up prove nothing other than demonstration of concept. In fact, the notable increase in compliance at 1 month may presage vulnerability to aneurysm formation in a pulsatile vascular bed with systolic pressure considerably greater than what exists in the Fontan circulation. Even a suggestion of durable and safe function will require a larger animal study with much longer followup-not an easy task. For now, we can offer encouragement and be grateful that talented individuals such as these authors are developing and testing innovative technology to help congenital heart surgery patients.

\section{References}

1. Yeung E, Inoue T, Matsushita H, Opfermann J, Mass P, Aslan S, et al. In vivo implantation of 3D printed customized branched tissue engineered vascular graft in porcine model. J Thorac Cardiovasc Surg. 2020;159:1971-81.e1.

2. Benrashid E, McCoy CC, Youngwirth LM, Kim J, Manson RJ, Otto JC, et al. Tissue engineered vascular grafts: origins, development, and current strategies for clinical application. Methods. 2016;99:13-9.

3. Sugiura T, Matsumura G, Miyamoto S, Miyachi H, Breuer CK, Shinoka T. Tissue engineered grafts in children with congenital heart disease: intermediate term follow-up. Semin Thorac Cardiovasc Surg. 2018;30:175-9.

4. Bockeria LA, Svanidze O, Kim A, Shatalov K, Makarenko V, Cox M, et al. Total cavopulmonary connection with new bioabsorbable vascular graft: first clinical experience. J Thorac Cardiovasc Surg. 2017;153:1542-50.

5. Shin'oka T, Matsumura G, Hibino N, Naito Y, Watanabe M, Konuma T. Midterm clinical result of tissue-engineered vascular autografts seeded with autologous bone marrow cells. J Thorac Cardiovasc Surg. 2005;129:1330-8. 
6. Kirkton RD, Santiago-Maysonet M, Lawson JH, Tente WE, Dahl SLM, Niklason LE, et al. Bioengineered human acellular vessels recellurize and evolve into living blood vessels after human implantation. Sci Transl Med. 2019;11:1-11.
7. Best CA, Szafron JM, Rocco KA, Zbinden J, Dean EW, Maxfield MW, et al. Differential outcomes of venous and arterial tissue engineered vascular grafts highlight the importance of coupling long-term implantation studies with computational modeling. Acta Biomater. 2019;94:183-94. 